\title{
Turizm Perspektifinden Yabancılaşmanın Sosyo-Psikolojik Analizi: Günlük Yaşamdan Turistik Yaşama Yabancılaşma Döngüsü
}

Semra AKTAŞ POLAT, Department of Business Administration, Faculty of Business, Duzce University, Turkey; e-mail: semrapolat@duzce.edu.tr

Serkan POLAT, Department of Health Institutions Management, Faculty of Business, Duzce University, Turkey; e-mail: serkanpolat@duzce.edu.tr

\section{Socio-Psychological Analysis of Alienation in Tourism Perspective: The Alienation Cycle from Daily Life to Touristic Life}

\begin{abstract}
Alienation describes the mood of people who have become the tool rather than the goal in the functioning of the capitalist society. The man has alienated to product, business and most importantly himself because of depreciating against materials. The topic of the study is the man (tourist) who is looking for this spiritual poverty in leisure activities. The aim of this study is to demonstrate the socio-psychological relationship between alienation and tourism. Following the review of the literature demonstrating the relationship between alienation and tourism, the Alienation Cycle in Tourism was created. The cycle of alienation explains how a tourist, psychologically, participates in tourism activities and behaves in touristic life besides clarifying sociological environment of tourism.

Keywords : Alienation, Escape, Authenticity, Self-Actualizing, Tourist Psychology.

JEL Classification Codes : $\quad$ A140, D110, L830, M310, M390, Z130.

Öz

Yabancılaşma, kapitalist toplumun işlerliğinde amaç olmaktan ziyade bir araç haline gelen insanın ruh halini tanımlar. Madde karşısında değer kaybeden insan; ürüne, işine ve en önemlisi de kendisine yabancılaşmıştır. $\mathrm{Bu}$ çalışmada manevi yoksulluğunu, boş zaman etkinliklerinde arayan insan (turist) konu edinilmiştir. Çalışmanın amacı, yabancılaşma ve turizm arasındaki ilişkinin sosyo-psikolojik dinamiklerinin ortaya konulmasıdır. Yabancılaşma ve turizm ilişkisini ortaya koyan literatür incelemesinin ardından, Turizmde Yabancılaşma Döngüsü oluşturulmuştur. Turizmde Yabancılaşma Döngüsü ile turistin nasıl bir psikoloji ile turizme yöneldiği, turistik yaşamda nasıl bir psikoloji ile hareket ettiği ve aynı zamanda, turizmin nasıl bir sosyolojik ortamda yürütüldüğü açıklanmaktadır.
\end{abstract}

Anahtar Sözcükler : Y Yabancılaşma, Kaçış, Otantiklik, Kendini Gerçekleştirme, Turist Psikolojisi. 


\section{Giriş}

Yabancılaşma, turizm literatüründe çok fazla ilgi gören bir konu olmamakla birlikte, turizm teorisi incelendiğinde turistin tanımlandığı (MacCannell, 1973; 1976), turist deneyimlerinin incelendiği (Cohen, 1979; Wang, 1999) ve turist motivasyonlarının araştırıldığı (Dann, 1977) çalışmalarda turizm ve yabancılaşma olgusunun ilişkilendirildiği görülmektedir. Turizmin sosyolojik ve psikolojik analizini farklı yönleri ile değerlendirmeye imkân sağlayan önemli bir olgu olmasına rağmen, yabancılaşma kavramı, turizm araştırmalarında hemen hemen hiç araştırılmamaktadır (Xue vd., 2014: 186; Dann \& Cohen, 1991: 165).

Modernleşme ve kapitalizmin bir sonucu olarak tartışılan yabancılaşma, tanıdık ve bildik olandan ayrılmayı ifade etmektedir. Çok eskilere dayanan yabancılaşma kavramı, eskiden akıl hastalarını tanımlamak için kullanılmıştır (Fromm, 2006: 116). Günümüzde, bu kavramın akıl hastalığı çerçevesinden çıkarıldığı görülmektedir. Hegel (2004) varlık problemi çerçevesinde, insan bilincinin gelişimini incelemiş, yabancılaşmayı öznel bir yaklaşımla değerlendirmiş ve kendisine yabancı olan Tin'den bahsetmiştir. Hegel'e göre (2004: 316) dünya, varlığını öz bilincin kendisini dışlaması ve özsüzleşmesi yoluyla kazanır ve bu oluş süreci kişiliğin yabancılaşmasıdır.

Marx ise yabancılaşmayı daha çok nesnel açıdan yorumlamıştır. Marx'ın (2003: 64) düşüncesinde yabancılaşma, insanın kendi ürettiği nesnenin karşısında saygınlığını ve değerini yitirmesi durumudur. Marx'a göre kapitalist toplumda din, devlet, politika ve ekonomi gibi tüm temel kurumsal alanlara bir yabancılaşma durumu vardır (Coser, 2008: 63). Marx (2003: 62), işyerinde yabancılaşma üzerinde önemle durarak işçinin, ürettiği kadar yoksullaştığını, değersizleştiğini ve emeğin nesnelleştiğini ifade etmektedir. Marx'a göre, işçinin yabancılaşması, dört aşamada gerçekleşmektedir (Ritzer 1992):

- İlk olarak kapitalist toplumda işçi, kendi üretici etkinliğine yabancılaşır.

- İkinci olarak işçi, yalnız üretici etkinliğine değil, aynı zamanda bu etkinliğin nesnesi olan ürüne de yabancılaşır.

- Üçüncü olarak kapitalizmde işçi, birlikte çalıştığı işçilere yabancılaşır.

- Son olarak ve en genel düzeyde, kapitalist toplumda işçi, kendi insani potansiyeline yabancılaşır.

Marx ve Weber, akılcılaşma ve yabancılaşma kavramları ile kapitalizme eleştirel bir anlayış ile karşı çıkmışlardır (Löwith, 2003: 27-34). Bu bağlamda Weber'in "demir kafes" metaforu önemli bir çıkış noktası olarak görülebilir. Dünyevi mallar ile ilgili kaygılar, insanın her zaman üstünden atabileceği ince bir palto gibi yalnızca azizlerin üzerinde durmalıdır (Baxter'dan (ty) akt. Weber, 1997: 159). Kader, bu paltodan demir 
kafesin oluşmasına hükmeder ve dünyevi mallar zamanla insanlar üzerinde güç kazanır (Weber, 1997: 159).

Fromm (1996: 105), yabancılaşma olgusunu, Marx'ın yaklaşımına benzer bir şekilde yorumlamış ve kapitalist toplumda bireyin, ekonomik amaçların aracı olarak boyun eğdiğini, kendi eliyle ürettiği ürüne yabancı hale geldiğini ifade ederek, bu durumu insanın dünyanın önünde eğilmesi, elinden geldiği kadar onu mutlu etmeye, eğitmeye ve düzeltmeye çalışması ile yorumlamıştır.

Yabancılaşma, bu çalışmada iki farklı açıdan yorumlanmıştır: Yabancılaşma kavramı ilk olarak, günlük yaşamında modernleşme ve kapitalizmin etkisiyle çevresine, ürettiği ürüne ve özellikle de kendisine yabancılaşan bireyden bahsetmek için kullanılmıştır. Sonrasında ise günlük yaşamda işine, çevresine ve kendine yabancılaşan bu bireyin, turistik yaşamda, turizm destinasyonunun kültürüne, çevreye ve yerel halka olan yabancılaşma halini tanımlamak için kullanılmıştır.

Yabancılaşmanın merkezde konumlandırıldığı bu çalışmanın amacı, yabancılaşma ve turizm arasındaki ilişkinin sosyo-psikolojik dinamiklerinin ortaya konulmasıdır. Yabancılaşma ve turizm arasındaki bağlantı, yabancılaşma literatürünü takip eden çalışmaların ardından, konuyu turizm araştırmalarına taşıyan çalışmalarda aranmıştır. Yabancılaşmanın günlük yaşamda nasıl bir formda olduğu ve turistik yaşamda nasıl bir forma dönüştügüu, Turizmde Yabancılaşma Döngüsü ile yorumlanmaya çalışılmıştır.

\section{Turizmde Yabancılaşma Döngüsü}

$\mathrm{Bu}$ çalışmada, yabancılaşma olgusunun günlük yaşamdan, turizm destinasyonuna uzanan seyrini takip etmek amacıyla "Turizmde Yabancılaşma Döngüsü (TYD)" kavramı kullanılmıştır. Bu kavram, bireyin günlük yaşamında ürüne, işine, çevresine ve kendisine yabancılaşmasından, bu yabancılaşmadan kaçışına, otantiklik ve kendini gerçekleştirme arzusunu tatmin etmek için turizm destinasyonunda yaşadığ 1 deneyimlerden, turizm destinasyonunda kültüre, çevreye ve yerel halka olan yabancılaşmasına kadar uzanan süreci anlatmak için kullanılan bir kavramdır. TYD, bireyin hem günlük yaşamda yaşadığı yabancılaşmayı hem de turist olduğunda yaşadığı yabancılaşmayı açıklığa kavuşturmaktadır.

TYD’nin merkezinde turizmin öznesi olarak tanımlayabileceğimiz turist yer almaktadır. Turizm deneyimlerinin gerisinde yatan nedenlerden "yabancılaşmanın" (MacCannell, 1973; Moore vd., 1995; Steiner \& Reisinger, 2006) ele alındı̆̆ turistin günlük yaşamında ve turizm deneyimi esnasında yaşadığı yabancılaşma duygusunun izlerini takip etmektedir. Böylece yabancılaşma olgusu, turistin nasıl bir psikoloji ile hareket ettiğini ortaya koymaktadır. 


\subsection{Günlük Yaşamda Yabancılaşma}

Günlük yaşam, turizm çalışmalarında, turistin geride bıraktığı alanı ifade etmek için kullanılmıştır. Turizm yazınında, turistin geride bıraktığı bu alanı ifade etmek için; günlük yaşam/rutin (Dann, 1977; Gottlieb, 1982; Steiner \& Reisinger, 2006; Cohen \& Cohen, 2012), sıradan yaşam (Cohen, 1985a), ev (Redfood, 1984) ve ev ortamı (Cohen, 1985b) gibi ifadelerin kullanıldığı görülmektedir.

Günlük yaşam, sahip olunan aile, iş, akraba ve arkadaşlarla örülü olan yaşamı ve bu yaşamın sürdürüldüğü çevreyi ifade etmektedir. Bu yaşam kültürel, sosyal, ekonomik, yasal ve politik yapının yanı sıra, örf, adet, gelenek ve din gibi faktörlerin de etkili olduğu bir çevrede sürdürülür. Günlük yaşam, yeryüzünde egemen olan endüstrileşme, modernleşme, küreselleşme ve postmodernizm gibi dalgalanmalardan etkilenmekte ve bu dalgalanmalara göre şekillenmektedir. Günlük yaşam, bu dalgalanmaların etkisiyle gün geçtikçe belirli kalıplar içine hapsolmaktadır.

Kalıpların içinde sıkışıp kalan insan, zamanla mekanikleşmekte ve bunun sonucunda da çevresindeki insanlardan ve kendisinden uzaklaşarak günlük yaşam sembollerine yabancılaşmaktadır. Fromm (1985: 87), insanın kendisinden, çevresindeki insanlardan ve doğadan yabancılaşarak bir meta haline geldiğini ve böyle bir dünyada insan ilişkilerinin birbirine yabancılaştığını ifade etmiştir. Fromm (2006: 216), yabancılaşma ile insanın kendisini bir yabancı gibi hissetmesi durumunu anlatmıştır.

\subsection{1. Ürüne, İşe, Çevreye ve Kendine Yabancılaşma}

İnsanın, dünyanın varlığını koruması için ürettiği ürünlerin insanlar üzerindeki egemenliğinin, insanı aracı konumuna getirdiği ve insanın günlük yaşamın tezahürlerine yabancılaştı̆̆ görülmektedir. Kişinin ürüne, işine, çevresine ve kendisine yabancılaşması, kendinden sökülüp alınması (Lefebvre, 2013: 219) olarak tanımlanabilir.

Yabancılaşma, endüstrileşmenin, toplumsal yaşama getirdiği bir yüktür. Endüstrileşme, işine her gün aynı saatte başlayıp, aynı saatte mola veren, aynı işleri yapan ve aynı saatte işten ayrılan mekanik bireyler oluşturmuştur. İşçinin monotonlaşması onu, ürettiği ürüne, birlikte çalıştığı iş arkadaşlarına ve kendisine yabancılaştırmaktadır (Ritzer, 1992). Üretim faktörlerinden birisi olan insan, yaşamın ondan beklediğini yapmak için sürekli çaba sarf etmektedir (From, 1996). Böylece, üretimin bir aracı haline gelen insan, geriye dönüp baktığında manevi değerlerini yitirmekte, hatta düğün ve bayram gibi bazı değerler zamanla, tıpkı makine önünde çalışan insanın yaptığı gibi bir gerekliliğin yerine getirildiği seremoniye dönüşmektedir. Böylece, benlikler kaybolmakta, yaşam anlamsızlaşmaktadır. Bu bağlamda yabancılaşma, insanın günlük yaşamda yaşadığı bu monotonluk, onu kendinden ve çevresindekilerden yabancılaştırmaktadır. Bu duygu insanın, kendisini bir yabancı gibi hissetmesi (Fromm, 1985: 87-216) ile tanımlanabilir. Böyle bir duygu, insanın çevresi ve kendisi ile bağlantısını koparmasına (Lefebvre, 2013: 
227), çevresi ile kurduğu ilişkilerin nesnelleşmesine ve insanın yabancılaşmasına (Lukacs, 2014: 29; Adorno, 2000: 152) yol açacaktır.

Yabancılaşma, sadece yaşamın insandan beklediği şeylerle değil, insanın yaşamdan beklediği şeylerle de yorumlanabilir. İnsan, yukarıda bahsettiğimiz koşuşturmaca içine, hatta büyük kentlere neden girmektedir? Neden kırsaldan kente göç etmiştir? Daha iyi bir hayat, daha iyi bir eğitim ve daha iyi bir yaşam standardına ulaşmak amacı gibi görünse de bunun en önemli nedeni sahip olma arzusudur. İnsanın sahip oldukları da insanı yabancılaştırmaktadır. Mülkiyet, insanı insandan uzaklaştıran, insanları siniflara ayıran bir olgudur.

Mülkiyet, eşitsizliğe yol açmakta, bazen de insanı manevi yoksunluk içine sürüklemektedir (Rousseau, 2010: 59; Ollman, 2012: 308). Bu manevi yoksunluk ise insanı, kendinden ve özünden uzaklaştıran bir duygudur. İnsan, sahip oldukları ile kendi dünyasını şekillendirmekte ve böylece sahip olduklarının egemenliği altına girmektedir.

İnsanın dünyasını, sahip olduklarının doldurması (Kılıç, 1984: 58), insanın, kendi emeğinin karşısına bir "şey" olarak çıkması (Lukacs, 2014: 211) ve kendi dünyasının ayrıntılarını üretmesi, insanın, kendi dünyasından daha fazla ayrılmasına sebep olacaktır (Debord, 2010: 47). Böyle bir durum karşısında insan güçsüzleşecek, toplumsal değerler onun için bir şey ifade etmeyecek, aşırı rekabet ve bireysellik ön plana çıkacak, insanın benlik saygısı azalacak, kendini olumsuz değerlendirecek ve tatmin edici olmayan faaliyetlerle meşgul olarak ayrık/bağımsız bir kişiliğe (Seeman, 1975: 102; Seeman, 1983: 173-179; Seeman, 1959: 788) sahip olacaktır.

Teknolojik gelişmeler ile birlikte evlere giren ve günlük yaşam için olmazsa olmaz konumuna gelen bazı araçlar, üretim bantlarının dışında insanları, nesneler karşısında pasif ve güçsüz konuma getiren diğer bir unsurdur. Günümüzde, evlerin iç dizaynı televizyonun konumuna göre tasarlanmaktadır. İnsan, işten veya okuldan çıkıp evine geldiğinde oturduğu koltuk, açıldığında dünya ile iletişime geçtiği makinelerin karşısına konumlandırılmaktadır. Karmaşanın içinden çıkıp evine gelen bir insan, televizyon ya da bilgisayar karşısında sosyalleşmeye olan ihtiyacını giderememektedir. Zaten kendisi için ayırabileceği çok az zamanı vardır (Dann, 1977: 187). Bu az zamanı da bilgisayar ve televizyon gibi teknolojik aletler doldurmaktadır. İşyerinde/okulda kendisi gibi olamayan insan, eve geldiğinde de yine kendi doğasına özgü faaliyetlerden uzaktır. Böylece akıp giden bir yaşamda, insanın yaşadığı bu ruh hali ya da bu çalışmanın önerisiyle yabancılaşma hali insanı yalnızlaştırmakta, onu belirli kalıpların içine hapsetmektedir.

Yabancılaşma aynı zamanda modern dönemde, aile yapısında görülen değişim ile de yorumlanabilir. Dedelerin ve ninelerin de bulunduğu geniş aile yapısı, gün geçtikçe küçülmekte ve hayat üç-dört kişilik çekirdek aile yapısına hatta geç yaşta evlilik ve kadının çalışma hayatına katılması gibi unsurların da etkisi ile çocuksuz karı-kocadan oluşan iki kişilik çekirdekcik aile yapısına dönüşmektedir. Böyle bir yaşam alanında, dost ve 
akrabalara ayrılan zaman çok sınırlı olmakta, toplumsal değerler insan için bir şey ifade etmez konumuna gelmektedir. Modern hayat, insanı kendinden ve öz değerlerinden uzaklaştırıp, onu yabancılaştıran bir hal almaktadır.

Ancak zaman zaman insan, güçsüzlüğün, anlamsızlığın, kuralsızlı̆̆ın, toplumsal soyutlanmanın ve kendine yabancılaşmanın (Seeman, 1959) yaşandığı günlük yaşamdan uzaklaşmak istemektedir. Böylece, bu olumsuzluklardan uzaklaşarak kendi gerçekliğine yaklaşmaya çalışmaktadır. Bu çalışmada, insanın, günlük yaşamın kendisine yüklediği yabancılaşma halinden uzaklaşma isteği kaçış noktası ile yorumlanmıştır.

\subsubsection{Kaçış Noktası}

Maddenin hâkimiyeti ve özel mülkiyet "şeyleşme"ye neden olmuş, Weber'in (1997) de deyimi ile insan demir kafese girmiş ve güçsüzleşmiştir. İnsan emeği nesnelleşmiş (Lukacs, 2014), maddeler dünyası egemen olmuş (Kılıç, 1984), insan kendi dünyasının ayrıntılarını üretir olmuş (Debord, 2010), metalaşma ve karmaşa ortamı oluşmuş (Adorno, 2000; Adorno \& Horkheimer, 2011), manevi yoksunluk söz konusu olmuş (Rousseau, 2010), insan kendinden sökülüp alınmış (Lefebvre, 2013), birey ekonomik amaçların aracı olmuş ve dünyayı mutlu etmeye çalışır hale gelmiş (Fromm, 1996), mallar insanlar üzerinde egemen olmuş (Weber, 1997), nesneler değer kazandıkça, insanların değeri düşmüş (Marx, 2003) böylece öz bilinç kendisini dışlamış ve özsüzleşmiştir. Bunun sonucunda dünya, varlığını korumuş ancak insan, kendisine yabancılaşmıştır (Hegel, 2004).

Yabancılaşmadan kaçış noktasında kaçışın; kaçış arayışı, psikolojik hazırlık ve ayrılma olmak üzere üç farklı aşamada gerçekleştiği ifade edilebilir. Kaçış noktasının başlangıcı olan kaçış arayışı, yabancılaşan insanın, yabancılaşmadan kaçmak istemesi ile ortaya çıkan arayışı ifade etmektedir. İnsanın bu isteği onu, yabancılaşmadan kaçış için alternatifler aramaya yöneltmektedir. Her şeyin bir meta haline dönüştüğü bir dünyada insan, yabancılaşmadan kaçmak için boş zaman faaliyetlerine yönelmiştir (Cohen, 1979; MacCannell, 1976).

Psikolojik hazırlık, yabancılaşma olgusunun, insanı boş zaman tüketimine yönlendiren psikolojik bir unsur olduğu görüşünden hareketle, kaçış arayışının sonucunda bulduğu alternatifleri değerlendirme aşamasını ifade etmektedir. Psikolojik hazırlık evresi, kaçışı sağlayacağı düşünülen alternatiflerin değerlendirilmesinden sonra, kararın verilmesi aşamasıdır. $\mathrm{Bu}$ aşamada insan, birincil ya da ikincil bilgi kaynaklarından ve önceki deneyimlerinden yola çıkarak, kendisini günlük yaşamdan uzaklaştıracak ya da uzaklaştıracağını düşündüğü aracı tespit etmiştir. Bu çalışmanın önerisi ile kaçış aracı olarak turizm deneyimini tercih eden birey, bu tespitin ardından tatil için gerekli hazırlıklara başlamaktadır. Psikolojik hazırlık evresinde, tatile ne zaman ve nereye gidileceği, kiminle gidilip ne kadar süre kalınacağı ve ne kadar bütçe ayrılacağı gibi kararlar verildikten sonra, tatil için gerekli işlemlere (vize, uçak bileti, otel rezervasyonu, ziyaret edilecek müze ve diğer kültürel yerlerin belirlenmesi, vs.) başlanmaktadır. 
Kullanılacak ya da kullanılması tasarlanan her türlü tatil malzemesi, tatil için belirlenen zamana kadar bavullara doldurulmakta, turist olmak için tüm hazırlıklar devam etmektedir.

Ayrılma ise, yabancılaşmadan kaçış arayışında bulunan bireyin, psikolojik olarak hazırlanmasının ardından bir boş zaman faaliyeti olan turizm deneyimi için günlük yaşamdan ayrılma noktasını ifade etmektedir. Bu aşamada, artık tatil için belirlenen gün gelmiştir. Birey, seçtiği ulaşım aracı ile günlük yaşam alanından uzaklaşarak, turizm destinasyonuna ulaşmış, turistik yaşama geçiş yapmış ve bir turist olmuştur.

\subsection{Turistik Yaşamda Yabancılaşma}

Turistik yaşam, turistin turizm destinasyonunda deneyimlediği yeme-içme, kültürel varlıkların ziyareti ve eğlenme gibi boş zamana yönelik faaliyetleri içerir. Çalışmada, "turistik" kelimesinin tercih edilmesinin nedeni, turizm teorisine ilişkin literatürde bu kavramın turizme ve turiste özgü bazı olguları tanımlamak için kullanılmış olmasıdır. İlgili literatürde "turistik" kelimesinin; turistik deneyim (MacCannell 1973; Gottlieb, 1982; Redfoot, 1984; Pizam vd., 1991; Moore vd., 1995; Aho, 2001), turistik destinasyon (Cohen, 1988; Muller, 1991; Gartner, 1994), turistik motivasyon (Gibson \& Yiannakis, 2002), turistik çekicilik (Culler, 1981), turistik unsur (Sharpley, 2009), turistik etkinlik (Ritchie \& Goeldner, 1994), turistik alan (Var vd., 1977), turistik kültür (Picard, 1996), turistik rekabet (Buhalis \& Schertler, 1999), turistik etki (Jafari vd., 1990) ve turistik fayda (Baloğlu \& McCleary, 1999) formlarında kullanıldığı görülmektedir.

Turistik kelimesinin Türk Dil Kurumu (2015) Güncel Türkçe Sözlüğü'nde karşılığı; (1) Turizmle ilgili olan, (2) Turistlerin gereksinimlerini karşılama amacı gözeten, turistleri ilgilendirici niteliği olan şeklinde verilmişstir. Bu çalışmada, turistik yaşam; turizm destinasyonuna varıştan ayrılışa kadar geçen sürede, turistlere özgü yaşam biçimini ifade etmektedir.

İçinde bulunmak zorunda olduğumuz zaman dilimi, kendi istediğimiz şeyler yerine, sistemin bize sunduğu eylemleri yerine getirdiğimiz bir zamandır. Böyle bir ortamda insan yerine, meta değer kazanmaktadır. Bu durum kişide iki açlı̆̆ doğurmaktadır. Bunlardan birincisi otantiklik, ikincisi ise kendini gerçekleştirmedir. Yabancılaşmış modern insan, boş zaman faaliyetlerine (televizyon izleme, spor etkinliklerine katılma, turizm etkinliklerine katılma, doğa yürüyüşü vb.) katılarak, yaşamındaki yokluğu bir ölçüde gidermeye çalışmakta, böylece günlük yaşamından uzaklaşarak, bir anlamda günlük yaşamına yabancılaşmaktadır. $\mathrm{Bu}$ ihtiyacın giderilmesinde, bir boş zaman faaliyeti olan turizm etkinliklerinin öne çıktığı söylenebilir.

\subsubsection{Otantiklik ve Kendini Gerçekleştirme}

Yabancılaşmanın turizm ile ilgisinde, turizmi otantiklik arayışı üzerinden değerlendiren çalışmalar önemli bir yer tutmaktadır. MacCannell (1973; 1976) modern 
dünyada, gündelik hayatın otantik olmadığının varsayıldığını ve turistin yabancılaştığını ifade ederek; turizmin arkasındaki temel motivasyonun otantiklik arayışı olduğunu ve turistlerin sosyal, kültürel ve tarihsel öneme sahip yerleri ziyaret ettiklerini belirtmiştir. Moore ve diğ. (1995: 77) turizmi, turistin günlük yaşamında yokluğunu hissettiği otantiklik arayışı ile ilişkilendirmiştir.

Otantiklik ve kendini gerçekleştirme, yabancılaşma ile turizm arasındaki ilişkinin anlaşılmasında önemli bir yere sahiptir. Otantikliğin yanı sıra kendini gerçekleştirme de yabancılaşmanın bir sonucu, ancak turizm deneyiminin bir sebebidir. Dünyayı mutlu etmeye (Fromm, 1996) çalışırken, kendine yabancılaşan, Hegel'in (2004) ifadesi ile özsüzleşen insanın, manevi yoksulluğunu anlatan, aynı zamanda da turizm motivasyonu (MacCannell, 1973; Wang, 1999; Cohen 1988) olarak kabul edilen otantiklik ve kendini gerçekleştirme, özellikle aktif katılımı gerekli kılmaktadır. Böylece yabancılaşan insan, edilgenliğinden kısa bir süre sıyrılarak etken hale gelecek ve insanın gerçek benliğine ilişkin olan arayışı bir sonuç verecektir.

Günlük yaşamında yabancılaşan insanın, bu yabancılaşmasından turizm aracılığı ile uzaklaşma çabası içine girdiği ifade edilebilir. Turistik yaşamda, günlük yaşamın kodları altüst olacaktır ya da öyle olması beklenir. Günlük yaşamında ürettiği ürün karşısında yabancılaşan ve sistemin işlerliği adına çalışan insan, turistik yaşamda mutlu olması için çaba sarf edilen insan konumuna gelecektir. Bu nedenle turizm faaliyetleri, günlük yaşamında yokluğunu hissettiği özgünlüğe ilişkin çeşitli arayışlar içine giren insan için dengeleyici bir rol üstlenmektedir.

Turist, günlük yaşamda hissettiği eksikliği, gerçek kişiliğine uyumlu, duygu ve düşünceleri ile tutarlı, değer ve inançları doğrultusunda hareket ederek ve dilediği gibi davranarak (Harter, 2002: 382-383; Steiner \& Reisinger, 2006: 299-300; Wood vd. 2008: 386) gidermeye çalışacaktır.

Burada bahsedilen arayış, yabancılaşmadan uzaklaşmak isteyen insanın yöneleceği turizm türünü de göstermesi açısından önemlidir. Turistin günlük yaşamında eksikliğini hissettiği gerçeklik ve öze ulaşma isteği onu kültür turizmine (Steiner \& Reisinger, 2006: 309-311) yönlendirmektedir. Turist, benlik duygusunu artırmak, yaşam kalitesini artırmak ve tarihsel kökleri aramak (Yeoman vd., 2007: 1130-1131) gibi motivasyonlarla hareket ederek sosyal, kültürel ve tarihi mekânlar (MacCannell, 1973) ile geleneksel kültür ve kökeni çağrıştıran (Wang, 1999: 349-350) mekânlara yönelmektedir. Bu mekânlarda yaşadıkları deneyimler ile turist, bir anlamda alternatif bir yaşam arayışı ile kendi arayışı içine girerek varoluşsal deneyimlere yönelmektedir (Cohen, 1979: 183-190; Cohen, 1985a: 293-294).Turizm deneyimi, otantik deneyimleri yaşayan insanda, benlik yükseltme ve ego tatminini gerçekleştirerek (Dann, 1977: 184-187) ve günlük yaşama bir ölçüde meydan okuyarak, insana kendini gerçekleştirme fırsatı sağlayacaktır. 
Yabancılaşan bireyin, yokluğunu hissettiği özgünlük ve gerçeklik arayışı, onu turizm etkinliklerine yönlendirmektedir. Tablo 1'de turizm aracılığı ile yabancılaşmanın kodlarının nasıl çözüldüğü verilmeye çalışılmıştır.

Tablo: 1

\section{Turizm Aracılı̆̆ ile Yabancılaşmanın Kodlarının Tersine Çevrilmesi}

\begin{tabular}{ll}
\hline \multicolumn{1}{c}{ Günlük Yaşam } & \multicolumn{1}{c}{ Turistik Yaşam } \\
\hline $\begin{array}{l}\text { İnsan özsüzleşmiş } \\
\text { (Hegel, 2004) }\end{array}$ & İnsan kendi gerçeğine ulaşır \\
$\begin{array}{l}\text { Nesneler karşısında insanın değer yitirmesi } \\
\text { (Marx, 2003) }\end{array}$ & Nesneler, insanların mutluluğu için kullanılır \\
$\begin{array}{l}\text { Malların insanlar üzerinde egemen olması } \\
\text { (Weber, 1977) }\end{array}$ & İnsanlar, ürünler üzerinde egemendir \\
$\begin{array}{l}\text { İnsan, dünyayı mutlu etmeye çalışır } \\
\text { (Fromm, 1996) }\end{array}$ & İnsan mutlu olmaya çalışır/İnsan mutlu edilmeye çalışılır \\
$\begin{array}{l}\text { İnsan, ekonomik amaçların aracı olur } \\
\text { (Fromm, 1996) }\end{array}$ & Ekonomik araçlar, insanın gerçekliği ve otantikliğin aracı olur \\
$\begin{array}{l}\text { İnsan, kendinden sökülüp alınmıştır } \\
\text { (Lefebvre, 2013) }\end{array}$ & İnsan, kendinden alınan özgürlüğünü geri almıştır \\
$\begin{array}{l}\text { Manevi yoksunluk hissi } \\
\text { (Rousseau, 2010) }\end{array}$ & Otantiklik ihtiyacının giderilmesi ile birlikte, geri dönen maneviyat \\
$\begin{array}{l}\text { Maddeler dünyası } \\
\text { (Kllıç, 1984) }\end{array}$ & Turistin dünyası \\
$\begin{array}{l}\text { Kendi dünyasının ayrıntılarını üreten insan } \\
\text { (Debord, 2010) }\end{array}$ & Kendisi için tasarlanmış dünyanın ayrıntılarını tüketen insan \\
$\begin{array}{l}\text { Metalaşma } \\
\text { (Adorno, 2000) }\end{array}$ & Öznelleşme \\
\hline Kaymak: Yaza) &
\end{tabular}

Kaynak: Yazarlar tarafindan hazırlanmıştır.

Turizm etkinliklerine yönelen birey, turizm aracılığ 1 ile kendi gerçekliğine dönmeye çalışmaktadır. Günümüzde her şey Tablo 1'de verildiği gibi olmamaktadır. Turizm etkinliklerine yönelen tüm insanların, kendi gerçekliğini yakalayabilen insanlar olduğunu söylemek mümkün değildir. Ancak, yabancılaşmadan kurtulma güdüsü ile hareket eden bireyin, yabancılaşma duygusundan, istenilen kaçışı gerçekleştiğinde turistik yaşamın, günlük yaşam karşısındaki duruşunun, Tablo 1'de olduğu gibi olması beklenir.

Maslow'un (1954) motivasyon teorisinin başlangıç noktası, fizyolojik ihtiyaçlardır. Fizyolojik ihtiyaçlar giderildiğinde, güvenlik ihtiyacı, güvenlik ihtiyacı giderildiğinde, ait olma ve sevme ihtiyacı ortaya çıkacaktır. Sonrasında ise saygı ihtiyacı ortaya çıkar. Tüm bu ihtiyaçlar giderilse de hoşnutsuzluk ve huzursuzluğun gelişmesi kaçınılmazdır. Müzisyen, müzik yapmalı; şair, şiir yazmalı; ressam, resim yapmalıdır. Kişi kendisi ile barışık olmak istiyorsa, kendi doğasına sadık kalmalıdır. Bu ihtiyaç, kendini gerçekleştirme olarak adlandırılır (Maslow, 1954: 35-46). Tablo 2'de kendini gerçekleştiren insanın belirgin özellikleri yer almaktadır. 


\title{
Tablo: 2
}

\section{Kendini Gerçekleştiren İnsanın Belirgin Özellikleri}

\author{
Daha esnektir. \\ Çevreye ve çevresindeki insanlara kolayca adapte olabilir. \\ Mutsuzluktan muaftır. \\ Şükretme (şükran) yeteneğine sahiptir. \\ Şükretme yeteneği hayatını değerli kılar ve onu daha bilinçli hale getirir. \\ Mucizelere inanır. \\ Çok yönlüdür. \\ İnsani değerlerini, ortalama bir insana göre daha az yitirmiştir. \\ Daha doğal ve sade davranışlar sergiler. \\ Yapmaciklıktan uzaktır. \\ Kaynak: Maslow, 1954 'ten uyarlanmıştır.
}

Kendini gerçekleştirme arayışında olan turist, gündelik yaşam stresinin telafisisi için gerçek benlik ve ideal benlik arasındaki boşluğu daraltma çabası içine girer (Gnoth, 1997: 287). Çünkü ideal benlik, zirveye doğru yükselip turistik deneyime yönelirken; gerçek benlik, sevgi ve saygı ihtiyacı gibi varlık ihtiyaçlarına; benlik ise yeme-içme ve korunma gibi eksiklik ihtiyaçlarına yönelmektedir (Teja, 2013: 156). Böyle bir arayış, maddi kazanımların ötesinde değer duygusu ve derin bir anlam arayışıdır (Yeamon vd., 2007: 1128). Kendini gerçekleştirmeyi başaran turist, ziyaret ettiği yer ve kendisi ile ilgili derin bir memnuniyet duyarak kişisel tatmin duygusu yaşar (Pearce, 2003: 525). Uzun, soğuk ve karanlık kışın etkisinden uzaklaşarak, dost ve akraba ziyaretleri gerçekleştirmek için Kuzey Avrupa ülkelerinde yaygın olan charter turizmi (Louring, 2013: 217), artan tatil harcamaları, dışarıda yemek yeme, tiyatroya gitme, bir hafta sonu SPA'da sağlık harcaması ve rafting gibi özel deneyimler (Yeamon vd., 2007: 1128) kendini gerçekleştirme ve bireysel arayışın örnekleridir.

Turistin, turizm deneyiminden beklediği bu fayda ancak turistin, günlük yaşamından derin bir şekilde yabancılaşması ile mümkün olabilecektir (Redfood, 1984: 292-304). Turistin, günlük yaşamında hissettiği yabancılaşmanın düzeyine göre, turizm deneyiminden elde edilecek fayda arasında da bir ilişki olabilir. Örneğin, daha az yabancılaşmış turist; daha az kaygılı olabilir, daha az katı kurallara sahip olabilir ve daha fazla memnuniyet duygusu yaşayabilir (Cohen, 1988: 376). Turist, turizm deneyiminden beklediği faydaya ulaşamadığ 1 zaman turistin, günlük yaşamda yabancılaşmış olan bilinci, henüz özgürleşmemiş demektir (Redfood, 1984). Kültür turizminin aksine, kitle turizmine yönelen turist, otantiklik yerine akışa kapılmayı tercih etmesi nedeniyle (Steiner \& Reisinger, 2006: 312) yabancılaşmasından uzaklaşamaz. Kitle turisti, kültür turistinin aksine otantik olmayan etkinliklerden hoşlanır ve gerçek dünyayı umursamaz (Urry, 2009: 23). Boş zamanın tüketimini de sanayinin belirlediği, insanın kendi boş zamanının tadını çıkaracak özgürlüğünün olmadığı ve insanların beğenileriyle oynandığı (Fromm, 2006: 129) gerçeğinden hareketle, kitle turizmi faaliyetlerinin, yabancılaşmadan tamamen kurtulmaya izin vermeyeceği ifade edilebilir. 
Önceden hazırlanmış deneyim paketleri (paket turlar) de turistin yaşayabileceği, ancak tadına varamadığı deneyimler bütünüdür. Turizm deneyimi, bir taraftan kendi gerçekliğini arayan insan için yabancılaşmadan kaçış aracı olabilecekken diğer taraftan, yabancılaşmanın turistik yaşama da uzanmasıyla turizm deneyiminin yapay bir ortamda, yabancılaşmanın içinden bir sahne olmaktan öteye geçemeyeceği ifade edilebilir.

\subsubsection{Bir Yabancı Olarak Turist}

Turist, günlük yaşamdaki yabancılaşma halinden uzaklaşırken, turisti motive eden temel faktörlerden birisi de kültüre, çevreye ve yerel halka yabancı olma durumudur. $\mathrm{Bu}$ çalışmada turistin, turizm destinasyonunda yaşadığı yabancılık duygusunun, turist tarafından arzu edilen bir durum olduğu düşünülerek, özellikle kültürel deneyimlerin, yabancılaşma arayışının bir metaforu haline geldiği (McKercher \& du Crost, 2003: 56) düşüncesi ile hareket edilmiştir.

$\mathrm{Bu}$ düşünce, turistik yaşam alanının psikolojik arka planının yorumlanması açısından önemlidir. Turizm destinasyonu, turiste günlük yaşamındaki düzenini değiştirme firsatı sağlamaktadır. Turistin, turizm destinasyonuna ulaştığı andan, ayrıldığı ana kadar yaşadığı bu değişiklik, onun günlük yaşamından uzaklaşmasına yardımcı unsurlardandır. Böylece turistik yaşam düzeni, günlük yaşama ait rutinin tersine dönmesiyle sağlanacaktır. Turistin, turizm destinasyonunda yaşadığı bu özgürlük, o bölgede yaşayan yerel halk için garip karşılanmakta ve yerel halk tarafından turist, yabancı olarak görülmektedir. Turist aynı zamanda, tatilini geçirmek için gittiği turizm destinasyonunun kültürüne ve bu kültürün değerlerine de yabancıdır.

Turist, tatilde olduğu zaman diliminde kendi norm ve değerlerini de askıya almaktadır (Gottlieb, 1982). Turistik yaşamda, böyle bir psikoloji ile hareket eden turist, tatilde olduğu dönemde, günlük yaşamda kendisinden alınan özgürlüğüne kavuşmaya çalışmaktadır. Bu nedenle, turist olmanın kendisine vermiş olduğu yabancı olma durumunu çıkarları doğrultusunda kullanmaktadır. Ancak, turistin tatilde yaşadığı bu yabancılaşma duygusu bazı turistler için bir firsat olabilirken, bazı turistlerin ise korktuğu bir durum olabilmektedir (Cohen, 1972: 166; Cohen, 1979: 197; McKercher \& du Crost, 2003; Podemski, 2005; McKercher \& Lui, 2013). Bu açıklamalardan yola çıkarak turistin, yeni bir turizm destinasyonuna ulaştığında hissettiği yabancılığın, onun hem istediği hem de çekindiği bir durum olduğu ifade edilebilir.

Turistin, günlük yaşamından yabancılaştığı/yabancılaşmaya çalıştığı turistik yaşam, aynı zamanda yerel halkın yaşamını sürdürdüğü günlük yaşam alanıdır. Bu nedenle turistik yaşam, kendi içinde günlük yaşamı barındırmakta ve yaşam alanlarındaki böyle bir ayrım düşüncesi sadece zihinlerde gerçekleşmektedir. Turist çevreye, kültüre ve yerel halka yabancılaşırken aynı zamanda, turizm destinasyonunda günlük yaşamını devam ettiren yerel halkın yaşamış olduğu ürüne, işe, çevreye ve kendine yabancılaşma duygusu da devam etmektedir. 
Kişiliğini ve gülümseyişini (Fromm, 1996; Fromm 2004) turistlere bir ürün olarak sunan, turisti mutlu etmeye çalışan turizm çalışanı da kendisine yabancılaşmaktadır. $\mathrm{Bu}$ nedenle, turizm ve yabancılaşma ilişkisi sadece turist odaklı irdelenmemiş olsaydı turizm destinasyonunda yabancılaşmanın farklı boyutları ile yaşandığı konusu turist, yerel halk ve turizm çalışanları perspektifinden de tartışmaya sunulabilirdi.

\section{Turizmde Yabancılaşma Döngüsüne Bütüncül Bir Bakış}

Yabancılaşma olgusunun günlük yaşamdan, turizm destinasyonuna uzanan seyrini bütüncül bir şekilde görebilmek amacıyla oluşturulan TYD modeli, Şekil 1'de gösterilmektedir. TYD doğrultusunda, yabancılaşmanın günlük yaşam ve turistik yaşam arasındaki döngüsü takip edilmiştir. TYD, hem bireyin günlük yaşamda yaşadığ1 yabancılaşmayı, hem de turist olduğunda yaşadığı yabancılaşmayı açıklığa kavuşturmaktadır.

\section{Şekil: 1}

Turizmde Yabancılaşma Döngüsü

\begin{tabular}{|c|c|}
\hline Günlük Yaşam & Turistik Yaşam \\
\hline Ürüne, İşe, Çevreye ve Kendine \\
Yabancılaşma
\end{tabular}

TYD'de, yaşam alanı günlük yaşam ve turistik yaşam olarak ayrılmış ve yabancılaşma bu çerçevede incelenmiştir. TYD'de, bu iki farklı yaşam çerçevesinde dört farklı hücre tanımlanmıştır. Birinci hücrede, bireyin günlük yaşamda ürüne, işe, çevreye ve kendine yabancılaşması; ikinci hücrede, bireyin günlük yaşamda hissettiği yabancılaşma duygusundan kaçış arayışı, psikolojik hazırlık ve ayrılma aşamalarını içeren kaçış noktası; üçüncü hücrede, turistin turistik yaşamda, otantiklik ve kendini gerçekleştirmesi; dördüncü hücrede ise turistin, turistik destinasyonda kültüre, çevreye ve yerel halka olan yabancılaşması gösterilmiştir.

TYD'de günlük yaşam ve turistik yaşam olmak üzere iki farklı dönemden bahsedilmektedir. Günlük yaşam için iki unsur önerilmiştir. Bunlardan birincisi; insanın ürüne, işine, çevresine ve kendisine yabancılaşmasını ifade etmektedir. Ürüne, işe, çevreye ve kendine yabancılaşma, turistin günlük yaşamında nasıl bir psikolojiye sahip olduğunu 
göstermesi açısından önemlidir. TYD'de, günlük yaşam alanı için önerilen ikinci unsur ise gündelik yaşantısında ürettiği ürüne, yaptığı işe, çevresine ve en önemlisi de kendisine yabancılaşan bireyin, bu yabancılaşmasından kaçış noktasıdır. Bu kaçış, yabancılaşan insanı, boş zaman deneyimlerinden biri olan turizm etkinliklerine yöneltmektedir. Turizm etkinliklerine yönelik gerçekleşen eğilimle birlikte, günlük yaşamda hissedilen yabancılaşma duygusunun yoğunluğu, kaçış noktasında zamanla azalmaktadır.

TYD’de, günlük yaşamda yaşanılan yabancılaşmanın; insanı, turizm deneyimi için psikolojik olarak hazırladığı varsayılmış olmakla birlikte, kaçış arayışı ile beliren alternatiflerin de değerlendirilerek turizm deneyimine yönelme durumu da psikolojik hazırlık noktasında değerlendirilmiştir. Yabancılaşmadan kaçış isteği, psikolojik hazırlık evresinin tamamlanmasının ardından "ayrılma" aşaması ile sonlanmaktadır. Ayrılma, hem günlük yaşamdan uzaklaşmayı hem de konunun özü itibarı ile yabancılaşmadan ayrılmayı ifade etmektedir.

TYD’de, turistik yaşam alanı bağlamında da iki unsur önerilmiştir. Birincisi, yabancılaşan bireyin, yabancılaşmanın tüm kodlarını tersine çevirerek bu yabancılaşmasından kurtulmaya çalıştığı, otantiklik ve kendini gerçekleştirme arayışı olarak düşünülmüştür. Otantiklik ve kendini gerçekleştirme, turistin; günlük yaşamında, onu kendi gerçekliğinden uzaklaştıran her türlü iş, olay ve nesneden uzaklaşarak, kendi gerçekliğine döndürecek faaliyetlere yönelmesi ile yorumlanmıştır. Bu nedenle, TYD’nin bu evresi turizmin arkasındaki temel motivasyonun otantiklik arayışı (MacCannell,1973; MacCannell, 1976; Moore vd., 1995: 77) olduğu, bu arayışın ise günlük yaşamda hissedilen yabancılaşmanın sebep olduğu manevi yoksunluktan kaynaklandığı gerçeği ile TYD’ye eklenmiştir.

İkincisi ise, turistin turizm destinasyonunda yaşadığı kültüre, çevreye ve yerel halka olan yabancılaşmasıdır. Turizm deneyimi sürecinde, insanın ikinci bir yabancılaşma deneyimi yaşaması, Lefebvre'nin (2013: 221) boş zaman faaliyetlerinin de başka yabancılaşmalara yol açacağı düşüncesi ile örtüşmektedir. Esasında bu aşamada bahsedilen yabancılaşma, günlük yaşamından sıyrılarak turistik yaşama geçen turistin, farklı bir ortama girdiğinde hissettiği duygunun adıdır. Yabancılaşma ve yabancılaşmadan kurtulmanın yeni bir yabancılaşmaya yol açabileceği (Lefebvre, 2013: 221) düşüncesi ile TYD’ye eklenen bu hücre, turizm deneyiminin de kendi içinde yabancılaşmaya neden olabileceği düşüncesi ile yorumlanmıştır. Turizm teorisinde, turizm deneyimi ile ilişkili olarak değinilen yabancılaşma ve yabancı olma durumu TYD'nin bu parçasının temelini oluşturmaktadır. TYD'nin bu aşamasında turist, gittiği turizm destinasyonuna bir yabancidır.

Turizm destinasyonuna yabancılaşma insanın; kültür, yerel halk ve çevre gibi unsurlardan bir yabancı olarak, Ivanovic'in (2008) ifadesinde olduğu gibi ötekilik duygusuna kapılma halidir. Bu haliyle turistin yaşadığı söz konusu duygu, bir sorunmuş gibi görünse de gerçekte yaşamayı istediği bir duygudur. Çünkü turist, bir anlamda günlük yaşamından uzaklaşma çabası içindedir. Bu uzaklaşmayı mümkün kılan unsurlardan birisi 
de turistin, turistik yaşam alanında yabancı olmasıdır. Yabancı olarak kabul edildiğini bilen turist, "genel davranış" kalıplarının dışına çıkma ruhsatına sahip olduğunu düşünerek yabancı kimliği ile gittiği bölgenin kurallarına uyma zorunluluğundan muaf olduğu düşüncesiyle davranışlarına yön verebilir. Bir taraftan otantiklik ve kendini gerçekleştirme deneyimleri yaşayan turistler kültüre, çevreye ve yerel halka yabancı olma duygusunu yaşamaktadır. Diğer taraftan turistlerin, turistik yaşam alanında sorunsuz bir şekilde zaman geçirmesi için çaba sarf eden turizm çalışanının, kendi benliğine olan yabancılaşması ve turistik yaşam alanı olarak adlandırılan bölgenin yerel halkının yabancılaşma süreci işlemeye devam etmektedir.

\section{Sonuç}

Yabancılaşmanın farklı boyutlarda ele alındığ 1 bu çalışmada, günlük yaşamında insanın yaşadığı yabancılaşmanın, turizm aracılığg ile nasıl bir forma dönüştüğü, TYD modeldi ile irdelenmiştir. TYD, günlük yaşam ve turistik yaşam ayrımından yola çıkarak; ürettiği ürüne, işine, çevresine ve kendisine yabancılaşan bireyin, yabancılaşmadan bir kaçış aracı olarak turizm etkinliklerine yönelmesini konu edinmiştir. TYD bu çerçevede, turizm etkinliklerine yönelen insanın; turizm deneyimi esnasında, bir taraftan otantik deneyimlerle kendi gerçekliğini yaşamaya çalışırken diğer taraftan yerel halk karşısında yabancı hale gelen ve turizm bölgesine yabancılaşan turisti değerlendirmektedir.

Yabancılaşma ve yabancılaşmadan kaçış aracı olarak turizmin ele alındığı bu çalışmada iki unsur TYD’ye dâhil edilmemiştir. Bunlardan birincisi, Urry'nin (1999: 206) ifade ettiği, zamanın çoğunun turist pratikleri ile geçirildiği postmodern dönemde, toplumsal alanlar ve kültürel alanların belirsizleşmesi ile birlikte turizmin mekânsız bir yapıya büründüğü düşüncesidir. Bu düşünce, Baudrillard'ın (2011: 14-15) günlük yaşam alanlarının gerçeklikten uzaklaştığı ve bir daha geri dönmeyeceği fikri ile bağdaşmaktadır. $\mathrm{Bu}$ gelişmeler, hem günlük rutinler arasında kalan hem de rutin dışı gerçekleştirilen etkinlikler olmak üzere tabakalı bir turizm etkinliğinden bahsedilmesine neden olmaktadır (Aktaş Polat, 2015: 133). TYD’ye dâhil edilmeyen ikinci unsur ise, turistik yaşam alanında gerçekleştirilen MacCannell'ın (1976) kullanmış olduğu "yabancılaştırılmış boş zaman" olgusuna ilişkin faaliyetlerdir. Yabancılaştırılmış boş zaman faaliyetleri, sistemdeki aktörler (turizm işletmecileri) tarafından hazırlanmış ve paket haline getirilmiş deneyimlerin, sistemin gerektirdiği gibi tüketilmesiyle oluşan ve derinliği olmayan yapay deneyimleri içerir. Söz konusu yapay deneyimler, Redfood'un (1984) belirttiği gibi yabancılaşmış bilinci özgürleştirmeyecek ve insanları günlük yaşamdaki yabancılaşmasından uzaklaştırmayacaktır. $\mathrm{Bu}$ nedenle tüm turizm deneyimlerinden aynı yararın elde edilemeyeceği, turizm deneyiminin, otantik olmayan yönünün de olduğu genel bir kabuldür. Bu kabul ile birlikte bu çalışmada, bireyin günlük yaşamında yaşamış olduğu yabancılaşma duygusundan arınma arayışına bir cevap olarak turizm deneyimi verilmiştir. $\mathrm{Bu}$ arayışa cevap vermeyen ya da vermeyeceği düşünülen kitle turizmi gibi otantik olmayan turizm deneyim biçimleri ile günlük yaşam alanlarında gerçekleştirilen turizm faaliyetleri TYD’ye dâhil edilmemiştir. 
Günlük yaşam içerisinde insanın, aidiyet duygusundan uzaklaşması onu bir arayış içine yöneltmektedir. Bu arayış, öze ve gerçekliğe dönme arzusundan başka bir şey değildir. Ancak yeryüzünün kurgusu yapay-sahte bir yapıya dönüşmekte ve bu nedenle öze ve gerçekliğe dönüş her zaman mümkün olamamaktadır. Bu nedenle, tüm insanların bu arayış içinde olduğu düşüncesi boş bir söylemden öteye gidemeyecektir. Günümüzde, kitle turizmine yönelen insanların sayısı göz önüne alındığında, böylesi bir arayışın tüm insanlar tarafından arzulanmadığg görülebilir.

Kitle turizmi ve iş turizmi etkinlikleri, insanların bu duygularını uyandırmak için tasarlanmamakta, tüm turizm türleri varoluşsal otantikliği aktif hale getirmemektedir (Xue vd., 2014: 195). Kültür turizmi ise alternatif otantikliğin tanınması ve üretilmesinde önemli role sahiptir (Ari \& Mittelverg, 2008: 82). Bu açıklamalardan yola çıkarak, turizmin tüm türlerinin insanı, yabancılaşmadan uzaklaştıracağını söylemek mümkün değildir. Böylesi bir gerçeklikten yola çıkarak, günlük yaşamda bireyin yaşadığı yabancılaşma duygusundan, bireyi uzaklaştırdığı düşünülen turizm etkinlikleri, özellikle bireysel olarak hareket eden turistlerin katıldığ tipine göre yorumlandığında günlük yaşamın kendisine empoze ettiği yabancılaşma duygusundan uzaklaşarak, otantiklik ve kendini gerçekleştirme arayışında olan turistler Cohen'in (1972) tanımladığı araştırmacı ve başıboş turistler, Plog'un (2001) maceracı turistler olarak tanımladığı dışa dönük turistler ve Smith'in (1989) tanımladığı araştırmacı ve sıra dışı turistlerdir. Tüm bu turist türlerinin ortak noktası; yeniliğe açık, aktif katılım sağlayan, heyecanı yüksek tutan, macerac1, enerjisi yüksek ve sıradan bir turistin deneyimlerinin dışında deneyimler aramalarıdır (Cohen, 1972; Plog, 2001; Smith, 1989).

Turizm ve yabancılaşma ilişkisinin irdelendiği TYD'nin, turizmde yabancılaşmayı bütün netliği ve tüm yönleriyle açıklaması mümkün görünmemektedir. TYD ile ilgili olarak; (1) günlük yaşamda herkesin yabancılaşıp yabancılaşmadığı, (2) Heideger'in (2008) ifade ettiği gibi kişinin, otantiklikle birlikte kendisine de yabancılaşıp yabancılaşmayacağı, (3) günümüzde otantik deneyimlerin gerçekte yaşanıp yaşanmadığı, (4) rafting ve sörf yapmak gibi turisti, aktif konuma getiren turizm etkinliklerinin, turiste tam anlamıyla kendini gerçekleştirme imkânı sağlayıp sağlamadığı, (5) günümüzde kültür turizmi uygulamalarının, gerçekten otantiklik ve kendini gerçekleştirme ihtiyacını giderip gidermediği, (6) gittikçe kalabalıklaşan turizm destinasyonlarında, yerel halka, kültüre ve çevreye karşı kendini yabancı hissettiği ifade edilen turist kalabalığı karşısında, yabancılaşmanın bu halini gerçekte yerel halkın turistler karşısında yaşayıp yaşamadığı, (7) Gottlieb (1982) ve Cohen'in (1985a) bahsettiği gibi, turizm bir oyun ve turist bir oyuncu ise, turizmin yabancılaşmadan izolasyonu sağlamasının mümkün olup olmadığ1, (8) TYD'nin tüm varsayımları doğruysa turistin, turistik yaşamdan ayrıldıktan ne kadar süre sonra tekrar günlük yaşamdaki yabancılaşma haline uyum sağlayacağ gibi çeşitli sorularla, TYD farklı bakış açılarından yorumlanabilir.

Yabancılaşma teorisinin turizm kapsamında yeniden yorumlanmasını içeren bu çalışmanın, turizmin sosyolojik ve psikolojik analizindeki boşlukların doldurulmasına katkıda bulunacağı düşünülmektedir. Turistin nasıl bir ruh hali içerisinde hareket ettiğini 
ve sergilediği davranışların arkasında yatan nedenleri ortaya koyması bu çalışmayı, mal ve hizmet üreten turizm işletmeleri ve bu tür işletmelere yatırım yapan taraflara, turisti daha yakından tanıma olanağı sağlaması bakımından önemli kılmaktadır.

\section{Kaynaklar}

Adorno, T.W. (2000), Minima Moralia Sakatlanmış Yaşamdan Yansımalar, (çev) O. Koçak \& A. Doğukan, İkinci Basım, İstanbul: Metis Yayınları.

Adorno, T. \& M. Horkheimer (2011), Sosyolojik Açılımlar Sunular ve Tartışmalar, (çev) M.S. Durgun \& A. Gümüş. Ankara: BilgeSu Yayıncılık.

Aho, S.K. (2001), "Towards a General Theory of Touristic Experiences: Modelling Experience Process in Tourism", Tourism Review, 56(3-4), 33-37.

Aktaş Polat, S. (2015), "Üstgerçeklik ve Turizmin Sonu”, Celal Bayar Üniversitesi, Sosyal Bilimler Enstitüsü Sosyal Bilimler Dergisi Beşeri Bilimler Sayıs1, 13(1), 120-137.

Ari, L.L. \& D. Mittelverg (2008), "Between Authenticity and Ethnicity: Heritage Tourism and Reethnification among Diaspora Jewish Youth”, Journal of Heritage Tourism, 7(2), 79-103.

Baloglu, S. \& K.W. McCleary (1999), “A Model of Destination Image Formation”, Annals of Tourism Research, 26(4), 868-897.

Baudrillard, J. (2011), Simulakrlar ve Simülasyon, (çev) O. Adanır, 6. Basım, Ankara: Doğu Batı Yayınlar1.

Buhalis, D. \& W. Schertler (1999), "Information and Communication Technologies in Tourism", Proceedings of the International Conference in Innsbruck, Austria, Springer Science \& Business Media.

Cohen, E. (1972), “Toward a Sociology of International Tourism”, Social Research, 39(1), 164-182.

Cohen, E. (1979), “A Phenomenology of Tourist Experiences”, Sociology, 13(2), 179-201

Cohen, E. (1985a), “Tourism as Play”, Religion, 15 (3), 291-304.

Cohen, E. (1985b), “The Tourist Guide: The Origins, Structure and Dynamics of a Role”, Annals of Tourism Research, 12(1), 5-29.

Cohen, E. (1988), “Authenticity and Commodization in Tourism”, Annals of Tourism Research, 15(3), 371-386.

Cohen, E. \& A.S. Cohen (2012), "Current Sociological Theories and Issues in Tourism", Annals of Tourism Research, 39(4), 2177-2202.

Coser, L.A. (2008), Sosyolojik Düşüncenin Ustaları Tarihsel ve Toplumsal Bağlamlarında Fikirler, (çev) H. Hülür \& S. Toker \& İ. Mazman, İkinci Baskı, Ankara: De Ki Basım Yayım.

Culler, J. (1981), "Semiotics of Tourism", The American Journal of Semiotics, 1(1-2), 127-140.

Dann, M.S.G. (1977), “Anomie, Ego-Enhancement and Tourism”, Annals of Tourism Research, 4(4), 184-194.

Dann, G. \& E. Cohen (1991), "Sociology and Tourism”, Annals of Tourism Research, 18(1), 155169.

Debord, G. (2010), Gösteri Toplumu, (çev) A. Emekçi \& O. Taşkent, 3. Basım, İstanbul: Ayrıntı Yayınlar1.

Fromm, E. (1985), Sevme Sanatı, (çev) I. Gündüz, İstanbul: Say Yayınları. 
Fromm, E. (1996), Özgürlükten Kaçış, (çev) Ş.Yeğin, 3. Basım, İstanbul: Payel Yayınları.

Fromm, E. (2004), Marx’ın İnsan Anlayışı, (çev) K.H. Ökten, İstanbul: Arıtan Yayınevi.

Fromm, E. (2006), Să̆llklı Toplum, (çev) Y. Salman \& Z. Tanrısever, 4. Basım, İstanbul: Payel Yayınevi.

Gartner, W.C. (1994), "Image Formation Process", Journal of Travel \& Tourism Marketing, 2(2-3), 191-216.

Gibson, H. \& A. Yiannakis (2002), "Tourist Roles: Needs and the Lifecourse”, Annals of Tourism Research, 29(2), 358-383.

Gnoth, J. (1997), “Tourism Motivation and Expectation Formation”, Annals of Tourism Research, 24(2), 283-304,

Gottlieb, A. (1982), “Americans' Vacations”, Annals of Tourism Research, 9(2), 165-187.

Harter, S. (2002), "Authenticity”, in (Eds) C.R. Synder \& Shane J. Lopez, Handbook of Positive Psychology, New York: Oxford University Press, 382-395.

Hegel, G.W.F. (2004), Tinin Görüngübilimi, (çev) A. Yardımlı, İkinci Baskı, İstanbul: İdea Yayınevi.

Heideger, M. (2008), Varlık ve Zaman, (çev) K.H. Ökten, Birinci Basım, İstanbul: Agora Kitaplığı.

Ivanovic, M. (2008), Cultural Tourism, Juta and Company Ltd. Cape Town, South Africa.

Jafari, J. \& A. Pizam \& K. Przeclawski (1990), “A Sociocultural Study of Tourism as a Factor of Change", Annals of Tourism Research, 17(3), 469-472.

Kılıç, S. (1984), Yabancılaşma İnsana Karşı Toplumsal Süreç, İstanbul: Rahmet Yayıncılık.

Lefebvre, H. (2013), Gündelik Hayatın Eleştirisi II Gündelik Hayat Sosyolojisinin Temelleri, (çev) I. Ergüden, İstanbul: Sel Yayıncilık.

Louring, J. (2013), "Creating the Tourist Product in the Opposition between Selfactualization and Collective Consumption: The Case of Charter Tourism”, Journal of Hospitality \& Tourism Research, 37(2), 217-236.

Löwith, K. (2003), Max Weber and Karl Marks, London and New York: Routledge.

Lukacs, G. (2014), Tarih ve Sinıf Bilinci, (çev) Y. Öner, 3. Baskı, İstanbul: Belge Yayınları.

MacCannell, D. (1976), The Tourist. A New Theory of The Leisure Class, University of California Press.

MacCannell, D. (1973), "Staged Authenticity: Arrangements of Social Space in Tourist Settings", The American Journal of Sociology, 79(3), 589-603

Marx, K. (2003), 1844 El Yazmaları Ekonomi, Politik ve Felsefe, (çev) K. Somer, Eriş Yayınları. Maslow, A.H. (1954), Motivation and Personality, Harper \& Row, Publishers, Inc.

McKercher, B. \& H. du Cros (2003), “Testing a Cultural Tourism Typology”, International Journal of Tourism Research, 5, 45-58.

McKercher, B. \& S.L. Lui (2013), “The Nine Safeties: How Inexperienced Tourists Manage The Strangeness of China", Journal of China Tourism Research, 9(4), 381-394.

Moore, K. \& G. Cushman \& D. Simmons (1995), "Behavioral Conceptualization of Tourism and Leisure”, Annals of Tourism Research, 22(I), 67-85.

Muller, T.E. (1991), "Using Personal Values to Define Segments in an International Tourism Market”, International Marketing Review, 8(1). 
Ollman, B. (2012), Yabancılaşma Marx’ın Kapitalist Toplumdaki İnsan Anlayışı, (çev). A. Kars, İstanbul: Yordam Kitap.

Pearce, P.L. (2003), "Self-Actuzaling”, in (Ed) J. Jafari, Encyclopedia of Tourism, Psychology Press. Routledge.

Picard, M. (1996), "Bali. Cultural Tourism and Touristic Culture", Archipelago Press, 231.

Pizam, A. \& J. Jafari \& A. Milman (1991), "Influence of Tourism on Attitudes: US Students Visiting USSR", Tourism Management, 12(1), 47-54.

Plog, S. (2001), "Why Destinations Areas Rise and Fall in Popularity, An Update of a Cornel Quarterly Classic, Cornel Hotel and Administration", Quarterly, 42(3), 13-24.

Podemski, K. (2005), Tourism as Commercialization Strangeness, in (Ed) W. Alejziak \& R. Winiarski, Tourism in Scientific Research.

Redfood, D.L. (1984), “Touristic Authenticity, Touristic Angst, and Modern Reality”, Qualitative Sociology, 7(4), 291-309.

Ritchie, B.J.R. \& C.R. Goeldner (1994), Travel, Tourism, and Hospitality Research: A Handbook for Managers and Researchers, Wiley.

Ritzer, G. (1992), Sociological Theory, (çev) Ü. Tatlıcan, Third Edition, McGraw-Hill.

Rousseau, J.J. (2010), İnsanlar Arasındaki Eşitsizliğin Kaynă̆ , (çev) R.N. İleri, 11. Baskı, İstanbul: Say Yayınları.

Rousseau, J.J. (1968), Politics and the Arts: Letter to M.D. 'Alembert on the Theatre, (çev) A. Bloom, (akt), R. Sennett (2010), Kamusal İnsanın Çöküşü, (çev) S. Durak \& A. Yılmaz, 3. Basım, İstanbul: Ayrıntı Yayınları.

Seeman, M. (1959), “On the Meaning of Alienation”, American Sociological Review, 24(6), 783791.

Seeman, M. (1975), “Alienation Studies”, Annual Review of Sociology, 1, 91-123.

Seeman, M. (1983), "Alienation Motifs in Contemporary Theorizing: The Hidden Continuity of the Classic Themes”, Social Psychology Quarterly, 46(3), 171-184.

Sennett, R. (2010), Kamusal İnsanın Çöküşü, (çev) S. Durak \& A. Yılmaz, 3. Basım, İstanbul: Ayrintı Yayınları.

Sharpley, R. (2009), Tourism Development and the Environment: Beyond Sustainablity?, Earthscan Publishes: UK.

Simmel, G. (2009), Bireysellik ve Kültür, (çev), T. Birkan, İstanbul: Metis Yayınları.

Smith, V.L. (1989), Hosts and Guests: The Antropology of Tourism, (Ed) V.L. Smith, Second Edition, Philedelphia, Pennsylvania: University of Pennsylvania Press, (Introduction, 121).

Steiner, C.J. \& Y. Reisinger (2006), "Understanding Existential Authenticity”, Annals of Tourism Research, 33(2), 299-318.

Teja, B.B. (2013), "Maslow's Self-Actualization and its Conflicting Theory Tending towards Indian Ethos", European Journal of Management Sciences and Economics, 1(3), 156-163.

Türk Dil Kurumu (2015), Turistik Kelime Anlamı, <http://www.tdk.gov.tr/index.php?option=com_gts\&arama=gts\&guid=TDK.GTS.559cf3 63438f34.63701347/>, 08.07.2015.

Urry, J. (1999), Mekanları Tüketmek, (çev), R.G. Ögdül, İstanbul: Ayrıntı Yayınları.

Urry, J. (2009), Turist Bakışı, (çev) E. Tataroğlu \& İ. Yıldız, Ankara: BilgeSu Yayıncılık. 
Var, T. \& R.A.D. Beck \& P. Loftus (1977), "Determination of Touristic Attractiveness of the Touristic Areas in British Columbia”, Journal of Travel Research, 15(3), 23-29.

Wang, N. (1999), "Rethinking Authenticity in Tourism Experience", Annals of Tourism Research, 26(2), 349-370.

Weber, M. (1997), Protestan Ahlakı ve Kapitalizmin Ruhu, (çev) Z. Aruoba, İkinci Baskı, İstanbul: Hil Yayın.

Wood, A.M. \& P.A. Linley \& J. Maltby \& M. Balousis \& S. Joseph (2008), "The Authentic Personality: A Theoretical and Empirical Conceptualization and The Development of The Authenticity Scale", Journal of Counseling Psychology, 55(3), 385-399.

Yeamon, I. \& D. Brass \& U. McMahon-Beattie (2007), "Current Issue in Tourism: The Authentic Tourist”, Tourism Management, 28, 1128-1138.

Xue, L. \& D. Manuel-Navarrete \& C.N. Buzinde (2014), "Theorizing The Concept Alienation in Tourism Studies”, Annals of Tourism Research, 44, 186-199. 
Aktaş Polat, S. \& S. Polat (2016), “Turizm Perspektifinden Yabancılaşmanın Sosyo-Psikolojik Analizi: Günlük Yaşamdan Turistik Yaşama Yabancılaşma Döngüsü”, Sosyoekonomi, Vol. 24(28), 235-253. 